\title{
Perbezaan Pandangan Masyarakat Melayu dan Cina Terhadap Dasar 1MALAYSIA: Satu Kes Kajian di Satok, Kuching
}

\author{
JUANITA SURAYA BT SHAMSUDIN, DICK LEMBANG DUGUN \& \\ STANLEY BYE KADAM-KIAI*
}

\author{
Faculty of Social Sciences and Humanities, Universiti Malaysia Sarawak, 94300 Kota Samarahan, Sarawak, \\ Malaysia \\ *Corresponding Author: bstanley@unimas.my
}

\begin{abstract}
ABSTRAK
Setelah mendapat keputusan tidak memuaskan pada Pilihan Raya Umum Ke-12 yang diadakan pada 8 Mac 2008 , maka Barisan Nasional $(\mathrm{BN})$, harus mencari alternatif untuk menarik semula perhatian rakyat Malaysia supaya kembali memilih dan menyokong BN seperti sebelum itu. Satu strategi yang digunakan Perdana Menteri Dato' Sri Mohammad Najib Tun Abdul Razak selepas mengambil alih pucuk kepimpinan negara pada tahun 2009 adalah dengan melancarkan Dasar 1Malaysia yang berbekal slogan 'Rakyat Didahulukan, Pencapaian Diutamakan'. Dasar 1Malaysia yang dilihat mempunyai sifat perpaduan, integrasi dan kesaksamaan pasti akan menggundang pelbagai reaksi daripada pelbagai kumpulan etknik yang terdapat di negara ini. Tujuan kajian ini adalah untuk menganalisa perbezaan dan persamaan pandangan dan interpretasi masyarakat Melayu dan Cina di Sarawak, terutama sekali di sekitar kawasan komersial Satok - iaitu tempat kajian dilakukan - terhadap Dasar 1Malaysia dari aspek pengetahuan am mengenai konsepnya, dan penerimaan dan persetujuan mereka terhadap idea tersebut. Objektif kajian ini adalah untuk menunjukkan bahawa wujudnya perbezaan persepsi dan interpretasi antara masyarakat Melayu dan masyarakat Cina berkaitan kefahaman terhadap Dasar 1Malaysia dan caranya dilaksanakan.

Kata kunci: Interpretasi, kaum, pandangan, perbezaan idea, persamaan pendapat

Copyright: This is an open access article distributed under the terms of the CC-BY-NC-SA (Creative Commons Attribution-NonCommercial-ShareAlike 4.0 International License) which permits unrestricted use, distribution, and reproduction in any medium, for non-commercial purposes, provided the original work of the author(s) is properly cited.
\end{abstract}

\section{PENGENALAN DAN LATAR BELAKANG}

Tahun 2008 begitu signifikan bagi politik tanah air kerana pada tahun tersebut kita dapat menyaksikan kepimpinan Barisan Nasional (BN) telah goyah. Tiada sesiapa yang berani menerpa bahawa, dalam pilihan raya negara yang ke12 (PRU-12) pada 8 Mac tahun itu, BN yang telah mentadbir negara sejak tahun 1957 akan hilang kepercayaan dua pertiga di Dewan Parlimen dan tewas di lima negeri iaitu di Kedah, Kelantan, Perak, Pulau Pinang dan Selangor. Prestasi BN di Kelantan juga semakin bertambah buruk. Perkara ini adalah satu keputusan yang mengejutkan dan BN seolah-olah hilang arah dan hilang keyakinan dan juga nampak kurang pasti dengan kewibawaan yang sedia ada. Walaupun, mereka tidak mengatakan demikian, namun keputusan pilihan raya yang ke-12, adalah satu episod yang sangat memalukan pucuk pimpinan dan penyokong UMNO (United Malays National Organisation) dan BN. Walaupun, parti pembangkang belum dapat menawan Dewan Parlimen, namun satu sorakan yang ditunjukkan oleh mereka seolah-olah mereka telah memenangi pilihan raya tersebut.

Kedudukan BN tidak lagi semantap dahulu kerana majoriti rakyat menaruh harapan tinggi supaya pihak BN mampu memimpin rakyat ke arah kehidupan yang lebih berkualiti. Sebenarnya banyak faktor yang menggoyahkan kedudukan BN. Antara faktor yang dianggap telah mempengaruhi keputusan pilihan raya ke-12 adalah seperti calon baharu, ketidakpuasan hati dalam kalangan sesama pemimpin parti, kadar kes jenayah semakin meningkat, rasuah berleluasa, penyalahgunaan kuasa dan pemilikan harta berlebihan dalam kalangan pemimpin, dan isu HINDRAF (Hindu Rights Action Force). Faktor-faktor ekonomi adalah seperi kenaikan harga minyak, harga barangan, bayaran tol, dan kenaikan kos sara hidup juga telah dianggap mempunyai peranan penting yang mengakibatkan kemerosotan sokongan pengundi kepada $\mathrm{BN}$. 
Lantaran itu, bagi meraih kembali kepercayaan rakyat, beberapa usaha pembaharuan perlulah dilakukan segera dan pada skala menyeluruh. Hal ini adalah penting kepada pihak kerajaan memandangkan perpaduan semakin lemah dalam kalangan rakyat akibat terlalu banyak konflik. Selepas mengambil alih kuasa daripada Tun Ahmad Badawi, Dato' Sri Mohammad Najib Tun Razak bertindak dengan melancarkan Dasar 1Malaysia pada skala menyeluruh dan besar-besaran untuk memulihkan keadaan BN yang telah kehilangan kepercayaan daripada penyokong-penyokongnya. Mengikut Bridgman dan Davis (1999), pertukaran tampuk kepimpinan negara biasanya akan membawa agenda baru kerajaan. Dengan ini demikian, seseorang pemimpin yang baru harus menggariskan dasar dan ideanya sebagai petunjuk bahawa nilai dan niat beliau berkaiatan isu-isu yang melanda masyarakat diberi perhatian dengan terperinci. Pelancaran dasar seperti Dasar 1Malaysia menunjukkan nilai dan niat seseorang ketua dan beliau akan mendominasi domain isu-isu tertentu (Baumer \& Van Horn, 2014).

Menyedari hakikat bahawa pihak kerajaan akan menghadapi kesukaran untuk memulih semula keadaan sekiranya mereka mengabaikan kepentingan seluruh rakyat tanpa mengira batasan kaum, agama mahupun latar belakang, maka Dasar 1Malaysia yang berbekalkan slogan, 'Rakyat Didahulukan, Pencapaian Diutamakan' ini dilaksanakan. Dasar ini secara keseluruhannya memfokuskan kepada perpaduan kesemua warganegara Malaysia yang terdiri daripada pelbagai kaum seperti Melayu, Cina, India, Iban, Kadazan dan lain-lain supaya bergerak sebagai satu kumpulan ke arah memajukan negara Malaysia dalam menuju dan merealisasikan Wawasan 2020.

Sebagai sebuah kerajaan yang bertanggungjawab, BN telah menggubal Dasar 1Malaysia bagi tujuan untuk memastikan keadilan serta kesaksamaan dapat dinikmati oleh segenap lapisan masyarakat dan kaum. Dasar 1Malaysia merupakan salah satu dasar awam di Malaysia yang memberikan implikasi terus kepada kehidupan rakyat. Dasar awam adalah mengenai tindakan-tindakan kerajaan yang dilakukan untuk sesuatu tujuan (Anderson, 2015; Hussain, 2002). Kerajaan akan memilih untuk membuat atau memilih tidak membuat sesuatu untuk menyelesaikan masalah yang dihadapi oleh rakyat. Gerston (2004) pula melihat dasar awam sebagai satu komitmen terhadap sesuatu. Berdasarkan pandangan ini beliau melihat dasar awam sebagai satunya respons terhadap matlamat baru, nilai baru, dan hubungan yang muncul akibat krisis atau konfrontasi. Bagi Denhardt, Denhardt dan Blanc (2014), dasar awam ialah tindakan politik untuk menghadapi realiti politi, manakala Kernaghan dan Siegel (1999) berpendapat bahawa dasar awam ialah satu tindakan khas kerajaan. Turner dan Hulme (1997), melabelkan cadangan khas, keputusan keraajaan dan program yang dilaksanakan kerajaan sebagai satu dasar. Perlaksanaan Dasar 1Malaysia melibatkan pelbagai program, projek, tindakan kerajaan seperti Bantuan Rakyat 1Malaysia (BR1M), Klinik 1Malaysia, Kedai Rakyat 1Malaysia, dan Komputer Rakyat (Netbook) 1Malaysia. Perlakasanaan kesemua ini memerlukan pengagihan sumber negara dan juga menggambarkan nilai seseorang pimpin. Oleh itu, Dasar 1Malaysia boleh dianggap sebagai dasar utama kerajaan pada masa itu.

Easton (1957), seorang ilmuwan sains politik yang tersohor menterjemahkan dasar awam sebagai satu nilai peruntukan pihak berkuasa bagi keseluruhan masyarakat. Ini bermakna sesuatu dasar yang diketengahkan oleh pihak berkuasa, iaitu kerajaan, adalah untuk keseluruhan masyarakat. Maka sesuatu dasar itu harus mempertimbangkan kesan yang bakal diterima oleh masyarakat sebelum diketengahkan. Manakala, Lasswell dan Kaplan (1970), mendefinisikan dasar awam sebagai sesuatu program yang telah ditetapkan matlamat, nilai dan pelaksanaanya. Ini menunjukkan pembuat dasar iaitu kerajaan, telah mengambil kira atau membuat pertimbangan sebelum melaksanakan sesuatu dasar. Jelas bahawa kerajaan mempunyai peranan yang signifikan dalam memperkenalkan mana-mana dasar yang secara langsung akan memberikan impak kepada kehidupan rakyat. Seperti Dasar 1Malaysia, kerajaan mempunyai peranan agar dasar yang diketengahkan dapat diterima oleh rakyat. Pembentukan dasar awam bertujuan untuk menyelesaikan masalah masyarakat.

Ironinya, sebagai sebuah kerajaan, BN telah mengambil pendekatan pragmatik memperkenalkan Dasar 1Malaysia bagi memupuk perpaduan, keadilan dan kesaksamaan bagi menjamin kestabilan negara. Politik dan dasar sukar untuk dipisahkan kerana aktor-aktor politik yang dipilih oleh rakyat yang akan menjadi penggubal dasar. Sebagai sebuah kerajaan, BN sedar seandainya mereka tidak menjalankan dasar yang lebih adil untuk rakyat Malaysia 
yang berbilang bangsa, maka, sudah tentu pada Pilihan Raya Umum yang seterusnya, akan menyebabkan pihak BN menghadapi tentangan yang lebih hebat. Isu perpaduan ditekankan kerana perpaduan rakyat merupakan elemen penting dalam integrasi nasional dan pembangunan negara. Maka pengenalan Dasar 1Malaysia sebagai teras dasar di Malaysia amat bertepatan untuk memupuk semangat perpaduan serta memastikan keadilan dan kesaksamaan dapat dirasa oleh semua rakyat.

\section{Pilihan Raya Umum Ke-12}

Keputusan PRU-12 ini merupakan keputusan paling buruk bagi BN dalam sejarah pilihan raya yang diadakan di negara kita. Namun begitu keputusan tersebut merupakan pencapaian terbaik bagi parti-parti pembangkang terutama bagi parti-parti pembangkang di Semanjung. Daripada 222 kerusi yang dipertandingkan, BN hanya mampu memenangi 139 kerusi sahaja. Sementara di peringkat DUN, pihak pembangkang berjaya menewaskan BN di lima buah negeri iaitu Kedah, Kelantan, Perak, Pulau Pinang dan Selangor. Manakala daripada 505 kerusi DUN yang dipertandingkan, hanya 307 buah kerusi yang mampu dimenangi oleh pihak BN (SPR, 2008; Wikipedia, 2008). Keputusan ini jelas membuktikan BN telah kekurangan sokongan daripada rakyat.

Akibat pola perubahan besar PRU-12 ini, maka ramai penganalisa politik melabelkan fenomena tersebut sebagai 'Tsunami Politik'. Senario ini juga telah dianggap sebagai “wake up call” bagi BN khususnya UMNO. Malah, PRU-12 tersebut telah mencatatkan bilangan undi rosak terbesar dalam sejarah Pilihan Raya Umum Malaysia. Keadaan ini juga menunjukkan bahawa para pengundi tidak berpuas hati dengan prestasi BN. Maka tindakan kerajaan memperkenalkan Dasar 1Malaysia adalah bertepatan.

Persepsi rakyat telah banyak berubah. Rakyat telah menolak kepimpinan BN seperti yang berlaku di Kedah, Pulau Pinang, Perak dan Selangor. Yang mengejutkan, ramai dalam kalangan orang Melayu telah meninggalkan BN dan menyokong PKR (Parti KeAdilan Rakyat) dan PAS (Parti Islam Se-Malaysia). Pengundi Cina pula meninggalkan MCA (Malaysian Chinese Association) dan Gerakan (Parti Gerakan Rakyat Malaysia) dan memberikan sokongan mereka kepada DAP (Democratic Action Party) dan juga PKR.

Rakyat Malaysia daripada pelbagai peringkat mempunyai harapan terhadap pucuk pimpinan Dato Sri Mohammad Najib Tun Abdul Razak untuk membawa perubahan positif untuk memacu negara ke tahap yang lebih tinggi. Tugas yang dipikul oleh Dato' Sri Mohammad Najib Tun Razak amat berat dalam mengembalikan keyakinan, kepercayaan dan sokongan rakyat Malaysia terhadap BN yang telah merekodkan keputusan terburuk dalam sejarah pilihan raya Malaysia selain daripada memulihkan keadaan kemelut ekonomi negara.

Yang pastinya ialah Dato' Sri Mohammad Najib Tun Razak telah menggantikan Tun Abdullah Ahmad Badawi pada waktu yang sangat mencabar dan kesan daripada Pilihan Raya Umum 2008 memerlukan perhatian kepimpinan yang matang daripada beliau. Masalah-masalah dan cabaran-cabaran yang melanda Malaysia akan menguji kesabaran dan kebolehan beliau untuk mengemudikan negara ini kepada tahap yang lebih cemerlang dan terbilang. Pada masa yang sama, masalah perpaduan kaum yang telah berlarutan begitu lama perlu diselesaikan jika $\mathrm{BN}$ ingin terus memegang tampuk kepimpinan negara. Persoalannya, mampukah BN mencapai perpaduan kaum dan meningkatkan taraf kehidupan rakyat melalui Dasar 1Malaysia?

Adakah Dasar 1Malaysia merupakan satu slogan yang bertujuan untuk memikat hati rakyat, mengubah persepsi mereka terhadap UMNO dan BN? Adakah Dasar 1Malaysia ini satu perjanjian BN dan rakyat bahawa BN akan mendahulukan rakyat. Dasar mengikut Lowi (1972), dapat menentukan politik tetapi tidak sebaliknya, bermakna tindakan kerajaan akan memastikan hala-tuju politiknya.

Sudah tentu, Dasar 1Malaysia bukanlah langkah pertama yang dilaksanakan oleh pihak kerajaan untuk mengatasi masalah pemisahan antara kepelbagaian bangsa di Malaysia. Sejarah ada menceritakan usaha Dato' Onn Jaafar dan Perdana Menteri kita terdahulu dalam usaha menyatupadukan rakyat tanpa mengira bangsa, namun ternyata 
rakyat masih keliru dan rata-ratanya tidak bersetuju dengan usaha ini. Jika ditelitikan daripada setiap kali negara bertukar Perdana Menteri, pastinya Perdana Menteri tersebut memperkenalkan slogan baru dengan harapan serta tujuan untuk membawa perubahan pada waktu pentadbiran mereka seperti 'Islam Hadhari' di bawah pemerintahan Tun Abdullah Ahmad Badawai, 'Malaysia Boleh' di bawah Tun Dr Mahathir Mohammad dan tidak kurang juga dengan 1Malaysia di bawah pentadbiran Dato' Sri Mohammad Najib Tun Abdul Razak.

\section{Dasar 1Malaysia}

Dasar atau gagasan 1Malaysia Dato' Seri Najib Tun Abdul Razak merujuk kepada satu masyarakat Malaysia yang dapat berdiri, berfikir dan bertindak sebagai satu banga negara. Apabila menerang maksud Dasar 1Malaysia ini, Dato' Seri Najib Tun Abdul Razak menyatakan:

Kita berdiri, kita berfikir dan bertindak sebagai bangsa Malaysia. Dan mengambil tindakantindakan berdasarkan kehendak semua kumpulan etnik dalam negara kita (Bahagian Penerbitan Dasar Negara, 2009).

Walau bagaimanapun, Dasar 1Malaysia ini masih tetap melaksanakan dasar sedia ada dan tidak akan:

... mengetepikan dasar afirmatif, dasar untuk menolong kaum Bumiputera asalkan dasar itu dilaksanakan dengan cara yang adil dan saksama dan memberi pertimbangan kepada golongan Bumiputera yang layak mendapat sesuatu pertimbangan daripada kerajaan (Bahagian Penerbitan Dasar Negara, 2009).

Yang penting, menurut Dato Seri' Najib, Malaysia sebagai sebuah negara berbilang bangsa tidak akan "bertindak dalam tembok etnik yang kita amalkan sejak sekian lama" Dari awal lagi, Malaysia telah dibelenggu masalah perpaduan kaum, integrasi nasional, dan pengaplikasian prinsip kesamarataan dan ekuiti (Bahagian Penerbitan Dasar Negara, 2009).

Kerajaan menaruh harapan dan mempunyai keyakinan yang tinggi bahawa Dasar 1Malaysia akan dapat menolong Malaysia untuk merealisasikan impiannya untuk menjadi sebuah negara maju pada tahun 2020. Terdapat tiga teras utama dalam gagasan 1Malaysia iaitu prinsip penerimaan, prinsip kenegaraan dan prinsip keadilan sosial dan lapan nilai yang menjadi terasnya. Nilai-nilai tersebut merangkumi perkara-perkara seperti budaya cemerlang, ketabahan, rendah hati, penerimaan, kesetiaan, meritokrasi, pendidikan dan integriti.

Dalam erti kata lain, konsep ini adalah untuk semua rakyat Malaysia tanpa mengira kaum, agama, dan budaya, serta tidak mengenal umur, jantina, taraf kehidupan dan sebagainya. Perkara ini diakui Yacob (2011) di dalam kajiannya di mana beliau mengatakan bahawa Dasar 1Malaysia ini adalah selaras dengan Perlembagaan Persekutuan. Cabaran kepada kerajaan ialah cara-cara untuk menyebarkan Dasar 1Malaysia kepada seluruh rakyat Malaysia agar konsep ini dikenali (Khairi, 2011). Berdasarkan dapatan kaji selidik Universiti Malaya, rakyat negara ini menerima secara umum Dasar 1Malaysia namun setiap kelompok kaum masih mempunyai tanggapan sempit terhadap dasar atau gagasan tersebut.

Dengan lain perkataan, rakyat Malaysia masih bimbang akan impak Dasar 1Malaysia itu terhadap kehidupan dan hubungan sesama mereka. Oleh hal yang demikian, dasar ini merupakan cabaran terhadap pemimpin negara daripada akar umbi untuk menterjermahkan retorik itu supaya menjadi kenyataan (Sinar Harian, 2012). 


\section{Persepsi Aspirasi Dasar 1Malaysia}

Ketika Dasar 1Malaysia mula dilancarkan oleh Perdana Menteri, pelbagai reaksi timbul dalam kalangan masyarakat kita. Masyarakat umum mulai membuat pentafsiran sendiri terhadap gagasan tersebut. Terdapat reaksi yang positif daripada berbagai-bagai kalangan masyarakat terhadap gagasan ini. Perasaan bimbang dan curiga terhadap hak dan tanggungjawab dalam kalangan pihak tertentu apabila terlaksananya gagasan ini tidak terlepas daripada benak fikiran masyarakat. Ada yang mempersoalkan banyak perkara mengenai Dasar 1Malaysia, ada juga yang menerimanya bulatbulat sahaja.

Oleh hal yang demikian, usaha untuk merealisasikan sesuatu dasar yang dilaksanakan bukanlah mudah dan amat rumit. Masih ramai rakyat Malaysia yang langsung tidak memahami sepenuhnya idea aspirasi falsafah di sebalik dasar yang telah digubal oleh Dato' Sri Mohammad Najib Tun Abdul Razak. Kebanyakan pihak menganggap bahawa dasar ini hanyalah retorik semata-mata dengan niat politik sahaja dan bukannya bertujuan demi kepentingan rakyat Malaysia secara keseluruhannya.

Kajian selidik Universiti Malaya menunjukkan rakyat menerima secara umum Dasar 1Malaysia, secara umum setiap kelompok kaum di negara ini masih mempunyai tanggapan sempit terhadap gagasan tersebut (Sinar Harian, 2012).

Setiap etnik mempunyai pandangan mereka sendiri tentang Dasar 1Malaysia dan walaupun sudah 55 tahun Malaysia mencapai kemerdekaan, namun jurang pemisah antara kaum masih wujud dengan ketara. Misalnya, kaum Cina ingin akan hak kesamarataan tanpa mengira bangsa, agama mahupun status. Namun, bagi orang Melayu masih merasakan mereka mempunyai hak untuk mempertahankan hak-hak keistimewaan iaitu "status quo" yang dinikmati selama ini.

Menyedari hakikat bahawa terdapat pelbagai persepsi masyarakat tentang Dasar 1Malaysia, maka pentingnya untuk mendekati masyarakat di luar bagi meninjau pendapat mereka tentang Dasar 1Malaysia kerana walaupun semua bangsa bergelar 'rakyat Malaysia', namun realitinya setiap bangsa dan agama masih memperjuangkan nasib atau hakhak yang diwakili oleh kumpulan masing-masing. Bukan itu sahaja mereka kuat mempertahankan identiti mereka tanpa memikirkan golongan lain, malah mereka akan bersaing untuk merebut hak serta peluang yang datang. Situasi ini merumitkan objektif Dasar 1Malaysia lagi kerana dasar tersebut mengkehendaki konsep pembinaan negara bangsa iaitu "Bangsa Malaysia" dicapai.

Dasar 1Malaysia memang satu usaha murni daripada pihak kerajaan, namun adakah dasar itu lebih dilihat sebagai satu usaha agenda politik kerajaan? Adakah slogan 'Rakyat Didahulukan, Pencapaian Diutamakan' hanyalah sekadar slogan lain seperti yang sedia maklum setiap kali ada Perdana Menteri baru maka sudah pasti terdapat slogan atau ungkapan yang akan diuar-uarkan oleh para Perdana Menteri. Antara slogan lain yang pernah dipopularkan oleh para Perdana Menteri kita adalah seperti 'Islam Hadhari', 'Malaysia Boleh', 'Cemerlang, Gemilang dan Terbilang', dan 'Wawasan 2020'. Memang benar bahawa kesemua slogan yang dipopularkan menjadi sebutan rakyat, namun rakyat masih kabur dengan slogan tersebut.

Jika hendak mentadbir terus negara ini, BN perlu menepati apa-apa yang telah dijanjikan. Namun kebanyakan rakyat sebenarnya mengkehendaki kepastian tentang sejauh mana pihak kerajaan sanggup membela untung nasib rakyat di Malaysia. Ekoran perbezaan persepsi masyarakat yang berbeza-beza terhadap dasar ini, maka sejauh manakah Dasar 1Malaysia ini mampu bertahan? 


\section{TEMPAT DAN METODOLOGI KAJIAN}

Kajian tentang persamaan dan perbezaan interpretasi Dasar 1Malaysia ini dijalankan di kawasan pusat komersial Satok, Kuching. Kawasan komersial Satok terletak di kawasan DUN Satok iaitu satunya Kawasan Pilihan Raya DUN yang terletak di Bandar raya Kuching dan satu-satunya kawasan yang majoriti penduduk dan pengundinya ialah orang Melayu. Kawasan komersial Satok, seperti kawasan komersial yang lain di negara ini sudah pasti didominasi oleh orang Cina, dan dikelilingi oleh berapa buah kampung Melayu seperti Kampung Melayu Satok. Lantaran itu, kaji selidik ini amat bertepatan untuk mengetahui pandangan masyarakat di kawasan Satok iaitu di Pusat Komersial Satok, Kuching, Sarawak.

Kaedah penyelidikan yang digunakan untuk mendapatkan maklumat ialah survei sosial dan instrumen penyelidikan yang digunakan ialah borang soal selidik. Temu bual bersemuka digunakan untuk memastikan maklumat yang tepat diperoleh. Kajian ini melibatkan 150 responden yang telah dipilih menggunakan persampelan secara rawak iaitu dalam kalangan peniaga di kawasan pusat komersial Satok. Data yang diperoleh telah diproses menggunakan SPSS.

\section{Persepsi Terhadap 1Malaysia}

Melalui maklumat yang diperoleh daripada maklum balas, didapati sama ada kaum Melayu mahupun kaum Cina, kesemuanya telah mengetahui Dasar 1Malaysia. Pihak Kerajaan BN telah berjaya memperkenalkan 1Malaysia kepada warganegara Malaysia hingga membolehkan mereka mengetahui kewujudan Dasar 1Malaysia yang dilaksanakan oleh kerajaan. Masyarakat bukan sahaja mengetahui Dasar 1Malaysia malah mereka juga mengetahui bahawa Dasar 1Malaysiaatau Gagasan 1Malaysia telah diilhamkan oleh Perdana Menteri Dato' Sri Mohammad Najib Tun Razak.

Pada awal perlaksanaan Dasar 1Malaysia, didapati bahawa bangsa Cina lebih banyak memberikan sokongan positif berbanding dengan bangsa Melayu. Empat puluh sembilan perpuluhan tiga peratus orang Cina mempunyai tanggapan bahawa Dasar 1Malaysia ialah satu dasar yang terbaik, manakala 26.7\% mempunyai tanggapan bahawa dasar tersebut adalah baik berbanding dengan 10.7\% dan 5.3\% tanggapan bagi orang Melayu (Jadual 1). Setelah dilaksanakan, kebanyakan golongan Cina yang menyokong perlaksanaan 1Malaysia pada peringkat awal didapati telah kurang memberikan sokongan terhadap dasar ini (Jadual 2). Hanya 4\% dan 14.7\% sahaja orang Cina mengatakan bahawa mereka sangat setuju dan setuju terhadap Dasar1Malaysia, manakala angka bagi orang Melayu ialah 16\% dan 54.7\%. Pada pendapat bangsa Cina (78.7\%), bahawa Dasar 1Malaysia hanyalah agenda politik pihak BN yang berunsur retorik semata-mata, berbanding dengan orang Melayu (9.7\%) (Jadual 7), walaupun kefahaman mereka (42.7\%) tentang dasar tersebut adalah lebih tinggi daripada bangsa Melayu (17.4\%) (Jadual 3).

Jadual 1. Tanggapan awal terhadap Dasar 1Malaysia (peratusan dalam parentesis).

\begin{tabular}{ccccccc}
\hline Etniksiti & Sangat Baik & Baik & Biasa & Kurang Baik & Sangat Kurang Baik & Jumlah \\
\hline Melayu & $4(5.3)$ & $8(10.7)$ & $21(28)$ & $21(28)$ & $21(28)$ & $75(100)$ \\
Cina & $20(26.7)$ & $37(49.3)$ & $8(10.7)$ & $5(6.7)$ & $5(6.7)$ & $75(100)$ \\
\hline Jumlah & $24(16)$ & $45(30)$ & $29(19.3)$ & $26(17.3)$ & $26(17.3)$ & $150(100)$ \\
\hline
\end{tabular}


Jadual 2. Persetujuan dengan Dasar 1Malaysia (peratusan dalam parentesis).

\begin{tabular}{ccccccc}
\hline Etniksiti & Sangat Setuju & Setuju & Kurang Setuju & Tidak Setuju & Sangat Tidak Setuju & Jumlah \\
\hline Melayu & $12(16)$ & $41(54.7)$ & $19(25.3)$ & $3(4)$ & $0(0)$ & $75(100)$ \\
Cina & $3(4)$ & $11(14.7)$ & $36(48)$ & $14(18.7)$ & $11(14.7)$ & $75(100)$ \\
\hline Jumlah & $15(10)$ & $52(34.7)$ & $55(36.7)$ & $17(11.3)$ & $11(7.3)$ & $150(100)$ \\
\hline
\end{tabular}

Jadual 3. Dasar 1Malaysia difahami oleh masyarakat (peratusan dalam parentesis).

\begin{tabular}{ccccccc}
\hline Etniksiti & Sangat Setuju & Setuju & Kurang Setuju & Tidak Setuju & Sangat Tidak Setuju & Jumlah \\
\hline Melayu & $5(6.7)$ & $8(10.7)$ & $13(17.3)$ & $37(49.3)$ & $12(16)$ & $75(100)$ \\
Cina & $12(16)$ & $20(26.7)$ & $21(28)$ & $19(25.3)$ & $3(4)$ & $75(100)$ \\
\hline Jumlah & $17(11.3)$ & $28(18.7)$ & $34(22.7)$ & $56(37.3)$ & $15(10)$ & $150(100)$ \\
\hline
\end{tabular}

Memang tidak dapat dinafikan bahawa Dasar 1Malaysia adalah merangkumi skop yang amat luas. Lantaran itu tidak hairanlah konsep ini mengundang kekeliruan, seterusnya mencetus interpretasi yang berbeza-beza dalam kalangan rakyat. Malah, hasil kajian turut berjaya membuktikan bahawa mesej-mesej Dasar 1Malaysia masih kabur dan tidak jelas di mata masyarakat Cina (21.1\%) berbanding dengan responden Melayu (54.7\%) (Jadual 4). Walau bagaimanapun, di sebalik kekeliruan dan pelbagai interpretasi, dapatan kajian menunjukkan bahawa orang Cina (24\%) lebih bersetuju dengan Dasar 1Malaysia jika dibandingkan dengan orang Melayu (10.6\%) (Jadual 5).

Sememangnya Dasar 1Malaysia mempunyai lapan nilai iaitu kesetiaan, meritokrasi, pendidikan, ketabahan, rendah hati, integriti, penerimaan dan budaya kecemerlangan. Kesemua nilai tersebut telah diketahui dan diterima pakai serta diaplikasi oleh kaum Melayu dan kaum Cina di pusat komersial Satok dalam kehidupan harian mereka.

Walau bagaimanapun, kedua-dua bangsa Melayu dan Cina mengalami keraguan, kerisauan dan kegusaran terhadap perlaksanaan konsep 1Malaysia. Bagi bangsa Melayu, mereka khuatir akan Dasar 1Malaysia kerana dasar itu boleh menjejaskan pencapaian ekonomi mereka manakala bangsa Cina pula ingin akan layanan hak sama rata daripada pihak kerajaan. Mereka berpendapat bahawa mereka bukan golongan pendatang. Oleh itu, mereka turut mahu menikmati hak seperti orang Melayu dan Bumiputera lain. Sementara itu, kebanyakan orang Melayu tidak mahu dilayan sama rata dengan kaum-kaum lain. Manakala kaum Cina terus mendesak dan menuntut agar pihak kerajaan melayan semua kaum dengan sama rata. Namun demikian kebanyakan orang Melayu berpendapat bahawa Dasar 1Malaysia ada menekankan prinsip kesemarataan. Oleh itu, sebanyak 44\% dan 16\% daripada mereka telah menafikan wujudnya prinsip kesemarataan dalam 'Dasar 1Malaysia' dengan menyatakan pendapat tidak bersetuju dan sangat tidak setuju terhadap penyataan tersebut (Jadual 22). Manakala, angka untuk orang Cina adalah masing-masing 28\% dan 4\%. Orang Melayu (58.7\%) juga menyatakan pendapat bersetuju dan sangat bersetuju bahawa Dasar 1Malaysia ada menekankan prinsip keadilan tetapi hanya 32\% orang Cina mempunyai idea yang sama (Jadual 23). Orang Melayu (72\%) juga mempunyai persepsi bahawa amalan-amalan Dasar 1Malaysia adalah selaras dengan konsep kebersamaan dalam satu keluarga besar, tetapi hanya $29.3 \%$ orang Cina bersetuju dan sangat setuju dengan pernyataan ini (Jadual 26). 
Jadual 4. Penyampaian Dasar 1Malaysia jelas di mata masyarakat (peratusan dalam parentesis).

\begin{tabular}{ccccccc}
\hline Etniksiti & Sangat Setuju & Setuju & Kurang Setuju & Tidak Setuju & Sangat Tidak Setuju & Jumlah \\
\hline Melayu & $17(22.7)$ & $24(32)$ & $25(33.3)$ & $6(8)$ & $3(4)$ & $75(100)$ \\
Cina & $6(8)$ & $10(13.3)$ & $13(17.3)$ & $15(20)$ & $31(41.3)$ & $75(100)$ \\
\hline Jumlah & $23(15.3)$ & $34(22.7)$ & $38(25.3)$ & $21(14)$ & $34(22.7)$ & $150(100)$ \\
\hline
\end{tabular}

Jadual 5. Penerimaan Dasar 1Malaysia oleh masyarakat umum (peratusan dalam parentesis).

\begin{tabular}{ccccccc}
\hline Etniksiti & Sangat Setuju & Setuju & Kurang Setuju & Tidak Setuju & Sangat Tidak Setuju & Jumlah \\
\hline Melayu & $4(5.3)$ & $4(5.3)$ & $23(30.7)$ & $30(40)$ & $14(18.7)$ & $75(100)$ \\
Cina & $3(4)$ & $15(20)$ & $28(37.3)$ & $21(28)$ & $8(10.7)$ & $75(100)$ \\
\hline Jumlah & $7(4.7)$ & $19(12.7)$ & $51(34)$ & $51(34)$ & $22(14)$ & $150(100)$ \\
\hline
\end{tabular}

Setelah 'Dasar 1Malaysia' dilancarkan oleh Dato' Sri Mohammad Najib Tun Abdul Razak dan dilaksanakan secara menyeluruh dan total, didapati bahawa sebahagian besar kaum Cina masih lagi tidak dapat melihat perubahan ketara tentang kebaikan dasar ini kepada masyarakat dan pembangunan negara. Hanya 24\% dalam kalangan mereka berpendapat bahawa Dasar 1Malaysia dilaksanakan secara menyeluruh dan menyentuh pelbagai aspek kehidupan masyarakat Malaysia khususnya dalam bidang ekonomi, politik dan sosial (Jadual 8). Walhal, bagi masyarakat Melayu sebanyak 59.4\% daripada mereka sangat bersetuju dan setuju bahawa dasar ini membawa banyak perubahan kepada Malaysia. Hal ini dibuktikan bahawa transformasi yang dilakukan oleh pihak kerajaan hanya mampu dirasai oleh golongan Melayu sahaja dan bukan terhadap golongan Cina. Dalam hal ini, pengkaji telah mendapati bahawa bangsa Melayu (64\%) mendapati amalan-amalan Dasar 1Malaysia selaras dengan slogannya iaitu, 'Rakyat Didahulukan, Pencapaian Diutamakan' (Jadual 25). Bagi bangsa Cina, hanya 29.3\% sahaja daripada mereka berpendapat bahawa amalan-malan 'Dasar 1Malaysia' adalah bertepatan dengan slogannya. Di bawah Dasar 1Malaysia, majoriti responden Cina (72\%) mengatakan bahawa soal hak bumiputera, bahasa, dan budaya harus dipertikaikan (Jadual 11). Sementara kaum Melayu, ada yang bersetuju (32\%) manakala ada pula yang tidak bersetuju (22.7\%) dan sangat tidak bersetuju (26.7\%) bahawa Slogan Dasar 1Malaysia tersebut hanyalah slogan komersial mengikut kaum Cina kerana hasil kajian telah membuktikan sebahagian besar masyarakat Cina (72\%) memberikan respon bahawa Dasar 1Malaysia tidak memperjuangkan nasib dan hak-hak semua kaum. Manakala masing-masing 38.7\% dan 22.7\% orang Melayu tidak setuju dan sangat tidak setuju dengan kenyataan tersebut (Jadual 13). Dalam erti kata lain, faedah Dasar 1Malaysia rata-rata dinikmati oleh bangsa Melayu (dan Bumiputera) sahaja.

Jadual 6. Tiada perubahan ketara terhadap negara semenjak Konsep 1Malaysia (peratusan dalam parentesis).

\begin{tabular}{ccccccc}
\hline Etniksiti & Sangat Setuju & Setuju & Kurang Setuju & Tidak Setuju & Sangat Tidak Setuju & Jumlah \\
\hline Melayu & $8(10.7)$ & $7(9.3)$ & $15(20)$ & $23(30.7)$ & $22(29.3)$ & $75(100)$ \\
Cina & $37(49.3)$ & $14(18.7)$ & $11(14.7)$ & $8(10.7)$ & $5(6.7)$ & $75(100)$ \\
\hline Jumlah & $45(30)$ & $21(14)$ & $26(17.3)$ & $31(20.7)$ & $27(18)$ & $150(100)$ \\
\hline
\end{tabular}


Jadual 7. Dasar 1Malaysia hanyalah retorik semata-mata (peratusan dalam parentesis).

\begin{tabular}{ccccccc}
\hline Etniksiti & Sangat Setuju & Setuju & Kurang Setuju & Tidak Setuju & Sangat Tidak Setuju & Jumlah \\
\hline Melayu & $4(5.3)$ & $3(4)$ & $38(50.7)$ & $28(37.3)$ & $2(2.7)$ & $75(100)$ \\
Cina & $39(52)$ & $20(26.7)$ & $6(8)$ & $6(8)$ & $4(5.3)$ & $75(100)$ \\
\hline \multirow{2}{*}{ Jumlah } & $43(28.7)$ & $23(15.3)$ & $44(29.3)$ & $34(22.7 \%)$ & $6(4)$ & 150 \\
\hline
\end{tabular}

Keputusan kaji selidik menunjukkan bahawa walaupun kedua-dua kaum tersebut mempunyai pandangan yang sama terhadap Dasar 1Malaysia, namun perbezaan pandangan antara kaum di Malaysia ini masih berkaitan teguh dengan isu perkauman. Banyak tafsiran yang diperkatakan mengenai Dasar 1Malaysia. Majoriti responden Melayu (65.3\%) juga berpendapat bahawa bahawa Dasar 1Malaysia merupakan langkah alternatif BN untuk menarik semula perhatian rakyat selepas PRU-12, tetapi hanya 24\% sahaja orang Cina bersependapat dengan perkara di sini (Jadual 9), dan bukan bertujuan untuk menyatupadukan rakyat. Majoriti responden, orang Melayu 81.3\% dan orang Cina $72 \%$, berpendapat bahawa Dasar 1Malaysia adalah untuk menarik perhatian kaum Cina (Jadual 10).

Jadual 8. Dilaksanakan secara menyeluruh dan menyentuh aspek kehidupan dalam bidang ekonomi, politik dan social (peratusan dalam parenthesis).

\begin{tabular}{ccccccc}
\hline Etniksiti & Sangat Setuju & Setuju & Kurang Setuju & Tidak Setuju & Sangat Tidak Setuju & Jumlah \\
\hline Melayu & $14(18.7)$ & $38(50.7)$ & $17(22.7)$ & $5(6.7)$ & $1(1.3)$ & $75(100)$ \\
Cina & $8(10.7)$ & $10(13.3)$ & $32(42.7)$ & $22(29.3)$ & $3(4)$ & $75(100)$ \\
\hline Jumlah & $22(14.7)$ & $48(32)$ & $49(32.7)$ & $27(18)$ & $4(2.7)$ & $150(100)$ \\
\hline
\end{tabular}

Jadual 9. Dasar 1Malaysia merupakan langkah alternatif BN untuk menarik semula perhatian rakyat selepas PRU-12 (peratusan dalam parentesis).

\begin{tabular}{ccccccc}
\hline Etniksiti & Sangat Setuju & Setuju & Kurang Setuju & Tidak Setuju & Sangat Tidak Setuju & Jumlah \\
\hline Melayu & $30(40)$ & $19(25.3)$ & $12(16)$ & $9(12)$ & $5(6.7)$ & $75(100)$ \\
Cina & $26(34.7)$ & $23(30.7)$ & $15(20)$ & $7(9.3)$ & $4(5.3)$ & $75(100)$ \\
\hline Jumlah & $56(37.3)$ & $42(28)$ & $27(18)$ & $16(10.7)$ & $9(6)$ & $150(100)$ \\
\hline
\end{tabular}

Jadual 10. Dasar 1Malaysia adalah untuk memancing undi golongan Cina (peratusan dalam parentesis).

\begin{tabular}{ccccccc}
\hline Etniksiti & Sangat Setuju & Setuju & Kurang Setuju & Tidak Setuju & Sangat Tidak Setuju & Jumlah \\
\hline Melayu & $37(49.3)$ & $24(32)$ & $5(6.7)$ & $7(9.3)$ & $2(2.7)$ & $75(100)$ \\
Cina & $27(36)$ & $27(36)$ & $15(20)$ & $3(4)$ & $3(4)$ & $75(100)$ \\
\hline Jumlah & $64(42.7)$ & $51(34)$ & $20(13.3)$ & $106.7)$ & $5(3.3)$ & $150(100)$ \\
\hline
\end{tabular}


Jadual 11. Di bawah Dasar 1Malaysia, soal hak Bumiputera dan Bahasa harus dipertikaikan (peratusan dalam parentesis).

\begin{tabular}{ccccccc}
\hline Etniksiti & Sangat Setuju & Setuju & Kurang Setuju & Tidak Setuju & Sangat Tidak Setuju & Jumlah \\
\hline Melayu & $12(16 \%)$ & $12(16 \%)$ & $14(18.7 \%)$ & $17(22.7 \%)$ & $20(26.7 \%)$ & $75(100)$ \\
Cina & $34(45.3 \%)$ & $20(26.7 \%)$ & $21(28 \%)$ & $0(0 \%)$ & $0(0 \%)$ & $75(100)$ \\
\hline Jumlah & $46(30.7 \%)$ & $32(21.3 \%)$ & $35(23.3 \%)$ & $17(11.3 \%)$ & $20(13.3 \%)$ & $150(100)$ \\
\hline
\end{tabular}

Malah, bagi orang Melayu, mereka tidak terlepas daripada perasaan khuatir serta bimbang bahawa Dasar 1Malaysia akan menggugat hak dan keistimewaan yang telah dinikmati mereka. Walaupun didapati terdapat pihak yang mempertikaikan dan mentafsir Dasar 1Malaysia berlainan, namun yang jelas dasar ini masih lagi berpaksikan Perlembagaan Persekutuan iaitu hak-hak keistimewaan orang Melayu dan Bumiputera terpelihara manakala hak-hak kaum lain akan terbela dan dihormati. Berikutan ramai yang masih kurang memahami pengertian sebenar Dasar 1Malaysia apabila hanya $46 \%$ orang Melayu dan $20 \%$ orang Cina berpendapat bahawa Dasar 1Malaysia berteraskan Perlembagaan Persekutuan (Jadual 12).

Seterusnya rata-rata bangsa Melayu dan bangsa Cina berpendapat bahawa Dasar 1Malaysia ialah bertepatan dengan suasana dan cita rasa rakyat Malaysia. Selain itu, kedua-dua kaum tersebut bersepakat bahawa Dasar1Malaysia menyukarkan proses transformasi bangsa Malaysia lagi. Bagi mereka Dasar 1Malaysia bukanlah jalan penyelesaian terbaik bagi mendekatkan jurang pemisah yang masih wujud dengan ketara antara kaum di negara tetapi merupakan langkah alternatif pihak BN untuk menarik semula perhatian rakyat Malaysia supaya kembali menyokong BN setelah kurang menyerlah pada PRU-12 pada tahun 2008 (Jadual 9).

Dapatan kajian menunjukkan perbezaan ketara antara kedua-dua kaum. Kedua-dua kaum tersebut didapati tidak sependapat bahawa di bawah Dasar 1Malaysia perpaduan rakyat Malaysia yang berbilang kaum dapat diperkukuh. Kaum Melayu di kawasan komersil Satok berpendapat bahawa perpaduan antara kaum mampu dipererat dengan adanya Dasar 1Malaysia dilancarkan pada skala besar-besaran. Namun tidak begitu bagi kaum Cina. Bukan itu sahaja mereka tidak yakin, malah mereka juga begitu pasti bahawa Dasar 1Malaysia tidak memperjuangkan nasib dan hak-hak semua kaum di Malaysia tanpa mengira latar belakang mereka. Menurut dapatan daripada kaji selidik, didapati tiada seorang pun bangsa Melayu dan bangsa Cina yang sangat tidak bersetuju bahawa Dasar 1Malaysia mencerminkan rakyat Malaysia saling bekerjasama (Jadual 14). Walau bagaimanapun, pernyataan tersebut hanya disokong kuat oleh bangsa Melayu (62.4\%) dan sebaliknya bagi bangsa Cina (24\%). Malahan orang Melayu (46.7\%) sangat menyokong pernyataan Dasar 1Malaysia bersifat "multiculturalism" (Jadual 15) dan liberalism (24\%) (Jadual 16), tetapi jawapan yang bertentangan telah diberikan oleh kaum Cina, iaitu masing-masing $21.4 \%$ dan $17.4 \%$.

Jadual 12. Dasar 1Malaysia berteraskan Perlembagaan Persekutuan (peratusan dalam parentesis).

\begin{tabular}{ccccccc}
\hline Etniksiti & Sangat Setuju & Setuju & Kurang Setuju & Tidak Setuju & Sangat Tidak Setuju & Jumlah \\
\hline Melayu & $10(13.3)$ & $32(42.7)$ & $12(16)$ & $17(22.7)$ & $4(5.3)$ & $75(100)$ \\
Cina & $4(5.3)$ & $11(14.7)$ & $38(50.7)$ & $22(29.3)$ & $0(0)$ & $75(100)$ \\
Jumlah & $14(9.3)$ & $43(28.7)$ & $50(33.3)$ & $39(26)$ & $4(2.7)$ & $150(100)$ \\
\hline
\end{tabular}


Jadual 13. Dasar 1Malaysia tidak memperjuangkan nasib dan hak-hak semua kaum (peratusan dalam parentesis).

\begin{tabular}{ccccccc}
\hline Etniksiti & Sangat Setuju & Setuju & Kurang Setuju & Tidak Setuju & Sangat Tidak Setuju & Jumlah \\
\hline Melayu & $5(6.7)$ & $6(8)$ & $18(24)$ & $29(38.7)$ & $17(22.7)$ & $75(100)$ \\
Cina & $27(36)$ & $27(36)$ & $8(10.7)$ & $8(10.7)$ & $5(6.7)$ & $75(100)$ \\
\hline Jumlah & $32(21.3)$ & $33(22)$ & $26(17.3)$ & $37(17.3)$ & $22(14.7)$ & $150(100)$ \\
\hline
\end{tabular}

Jadual 14. Dasar 1Malaysia mencerminkan rakyat Malaysia yang saling bekerjasama (peratusan dalam parentesis).

\begin{tabular}{ccccccc}
\hline Etniksiti & Sangat Setuju & Setuju & Kurang Setuju & Tidak Setuju & Sangat Tidak Setuju & Jumlah \\
\hline Melayu & $22(29.3)$ & $25(33.3)$ & $21(28)$ & $7(9.3)$ & $0(0)$ & $75(100)$ \\
Cina & $8(10.7)$ & $10(13.3)$ & $35(46.7)$ & $22(29.3)$ & $0(0)$ & $75(100)$ \\
\hline Jumlah & $30(20)$ & $35(23.3)$ & $56(37.3)$ & $29(19.3)$ & $0(0)$ & $150(100)$ \\
\hline
\end{tabular}

Jadual 15. Dasar 1Malaysia bersifat multicultralisme (peratusan dalam parentesis).

\begin{tabular}{ccccccc}
\hline Etniksiti & Sangat Setuju & Setuju & Kurang Setuju & Tidak Setuju & Sangat Tidak Setuju & Jumlah \\
\hline Melayu & $12(16)$ & $23(30.7)$ & $23(30.7)$ & $14(18.7)$ & $3(4)$ & $75(100)$ \\
Cina & $8(10.7)$ & $8(10.7)$ & $10(13.3)$ & $30(40)$ & $19(25.3)$ & $75(100)$ \\
\hline Jumlah & $20(13.3)$ & $31(20.7)$ & $33(22)$ & $44(29.3)$ & $22(14.7)$ & $150(100)$ \\
\hline
\end{tabular}

Jadual 16. Dasar 1Malaysia bersifat liberalism (peratusan dalam parentesis).

\begin{tabular}{ccccccc}
\hline Etniksiti & Sangat Setuju & Setuju & Kurang Setuju & Tidak Setuju & Sangat Tidak Setuju & Jumlah \\
\hline Melayu & $5(6.7 \%)$ & $13(17.3 \%)$ & $38(50.7 \%)$ & $14(18.7 \%)$ & $5(6.7 \%)$ & $75(100)$ \\
Cina & $8(10.7 \%)$ & $5(6.7 \%)$ & $14(18.7 \%)$ & $25(33.3 \%)$ & $23(30.7 \%)$ & $75(100)$ \\
\hline Jumlah & $13(8.7 \%)$ & $18(12 \%)$ & $52(34.7 \%)$ & $39(26 \%)$ & $28(18.7 \%)$ & $150(100)$ \\
\hline
\end{tabular}

Walaupun kebanyakan kaum Cina masih tidak berpuas hati terhadap perlaksanaan Dasar 1Malaysia, namun hakikatnya mereka tidak dapat menafikan dan harus menghargai segala bantuan dan kemudahan yang telah disumbangkan oleh pihak kerajaan. Antaranya adalah seperti pemberian Komputer Rakyat (Netbook) 1Malaysia yang dilihat majoriti Melayu (68\%) mampu merapatkan jurang digital antara kawasan bandar dan luar bandar, tetapi orang Cina mempunyai pandangan yang berbeza apabila hanya $16 \%$ sahaja mereka setuju dengan kenyataan ini (Jadual 17). Begitu juga dengan Skim Simpanan Persaraan 1Malaysia. Di sini juga majoriti besar orang Melayu (73.3\%) bersetuju dan sangat setuju dengan kenyataan bahawa Skim Simpanan Persaraan 1Malaysia ialah inisiatif kerajaan untuk memastikan golongan tiada pendapatan tidak mempunyai simpanan selepas bersara. Manakala, hanya 33.3\% orang 
Cina setuju dan sangat setuju dengan ayat tersebut (Jadual 18). Majoriti orang Melayu (66.6\%) juga berpendapat bahawa Golongan Pekerja Sendiri lebih terjamin dengan adanya Skim simpanan Persaraan 1Malaysia, berbanding $26.7 \%$ untuk orang Cina (Jadual 19). Golongan pekerja sendiri termasuklah mereka yang tidak mempunyai pendapatan tetap dapat menikmati skim ini iaitu mempunyai simpanan wang apabila mencapai umur persaraan. Pemberian Baucar Buku 1Malaysia pula mampu memupuk sifat minat membaca di samping meringankan beban perbelanjaan buku dalam kalangan pelajar Institut Pengajian Tinggi. Taraf hidup, mengikut Van der Berg (2001), adalah berkait rapat dengan pencapaian akademik. Perlaksanaan Kedai Rakyat 1Malaysia pula dapat membantu Perusahaan Kecil dan Sederhana. Seterusnya Klinik 1Malaysia menyediakan khidmat rawatan kesihatan asas pada kadar RM1. Sementara BR1M berupa wang RM500 juga dapat meringankan beban rakyat. Kesemua ini merupakan satu set keputusan pemilihan matlamat yang berhubung kait antara satu dengan yang lain dan bertujuan untuk mencapai dasar tersebut (Jenkins, 1993).

BR1M ialah satu dasar pengagihan semula berbentuk pemberian wang bernilai RM500.00. Dasar pengagihan semula ini disebut begitu kerana dasar ini melibatkan perkara seperti peralihan pembayaran, kebajikan dan kesihatan (Gerston, 2004). Melalui dasar ini, kerajaan akan dengan sengaja memindahkan kekayaan, pendapatan, harta atau hak dari satu kelas atau kumpulan kepada kelas dan kumpulan yang lain, iaitu daripada kumpulan yang berada kepada kumpulan yang kurang berada (Anderson, 2015). Ini bermkasud, dalam dasar pengagihan semula, ada kumpulan atau golongan penduduk yang akan menang dan ada yang akan rugi pula (Ripley \& Franklin, 1987). Insentif seperti BR1M bertujuan supaya golongan yang kurang mampu akan lebih bertanggungjawab terhadap kesejahteraan diri mereka (Dye, 1992). Begitu juga Baucar Buku 1Malaysia juga merupakan satu subsidi dan tujuan subsidi disalurkan adalah untuk memulihkan ketidakseimbangan dan ketaksamaan dalam kalangan masyarakat (Howlett \& Ramesh, 1995; Hughes, 1998).

Jadual 17. Program pemberian Netbook merapatkan jurang digital antara kawasan bandar dan luar bandar (peratusan dalam parentesis).

\begin{tabular}{ccccccc}
\hline Etniksiti & Sangat Setuju & Setuju & Kurang Setuju & Tidak Setuju & Sangat Tidak Setuju & Jumlah \\
\hline Melayu & $28(37)$ & $23(31)$ & $14(18.7)$ & $6(8)$ & $4(5.3)$ & $75(100)$ \\
Cina & $11(14)$ & $15(2)$ & $30(40)$ & $18(24)$ & $1(1.3)$ & $75(100)$ \\
\hline Jumlah & $39(2)$ & $38(25.3)$ & $44(29.3)$ & $24(16)$ & $5(3.3)$ & $150(100)$ \\
\hline
\end{tabular}

Jadual 18. Skim Simpanan Persaraan 1Malaysia adalah inisiatif kerajaan untuk memastikan golongan tiada pendapatan mempunyai simpanan selepas bersara (peratusan dalam parentesis).

\begin{tabular}{ccccccc}
\hline Etniksiti & Sangat Setuju & Setuju & Kurang Setuju & Tidak Setuju & Sangat Tidak Setuju & Jumlah \\
\hline Melayu & $16(21.4)$ & $39(52)$ & $15(20)$ & $4(5.3)$ & $1(1.3)$ & $75(100)$ \\
Cina & $13(17.3)$ & $12(16)$ & $28(37.3)$ & $19(25.3)$ & $3(4)$ & $75(100)$ \\
\hline Jumlah & $29(19.3)$ & $51(34)$ & $43(28.7)$ & $23(15.3)$ & $4(2.7)$ & $150(100)$ \\
\hline
\end{tabular}


Jadual 19. Golongan pekerja sendiri lebih terjamin dengan adanya Skim Simpanan Persaraan 1Malaysia (peratusan dalam parentesis).

\begin{tabular}{ccccccc}
\hline Etniksiti & Sangat Setuju & Setuju & Kurang Setuju & Tidak Setuju & Sangat Tidak Setuju & Jumlah \\
\hline Melayu & $13(17.3)$ & $37(49.3)$ & $19(25.3)$ & $3(4)$ & $3(4)$ & $75(100)$ \\
Cina & $11(14.7)$ & $9(12)$ & $41(54.7)$ & $14(18.7)$ & $0(0)$ & $75(100)$ \\
\hline Jumlah & $24(16)$ & $46(30.7)$ & $60(40)$ & $17(11.3)$ & $3(2)$ & $150(100)$ \\
\hline
\end{tabular}

Jadual 20. Dengan adanya Konsep 1Malaysia, pentadbiran negara menjadi lebih lancar (peratusan dalam parentesis).

\begin{tabular}{ccccccc}
\hline Etniksiti & Sangat Setuju & Setuju & Kurang Setuju & Tidak Setuju & Sangat Tidak Setuju & Jumlah \\
\hline Melayu & $8(10.7)$ & $32(42.7)$ & $24(32)$ & $10(13.3)$ & $1(1.3)$ & $75(100)$ \\
Cina & $7(9.3)$ & $17(22.7)$ & $25(33.3)$ & $23(30.7)$ & $3(4)$ & $75(100)$ \\
\hline Jumlah & $15(10)$ & $49(32.7)$ & $49(32.7)$ & $33(22)$ & $4(2.7)$ & $150(100)$ \\
\hline
\end{tabular}

Jadual 21. Melalui Dasar 1Malaysia tidak ada golongan yang dipinggirkan (peratusan dalam parentesis).

\begin{tabular}{ccccccc}
\hline Etniksiti & Sangat Setuju & Setuju & Kurang Setuju & Tidak Setuju & Sangat Tidak Setuju & Jumlah \\
\hline Melayu & $14(18.7)$ & $33(44)$ & $18(24)$ & $7(9.3)$ & $3(4)$ & $75(100)$ \\
Cina & $10(13.3)$ & $10(13.3)$ & $35(46.7)$ & $19(25.3)$ & $1(1.3)$ & $75(100)$ \\
\hline Jumlah & $24(16)$ & $43(28.7)$ & $53(35.3)$ & $26(17.3)$ & $4(2.7)$ & $150(100)$ \\
\hline
\end{tabular}

Jadual 22. Dasar 1Malaysia tidak menekankan prinsip kesemarataan (peratusan dalam parentesis).

\begin{tabular}{ccccccc}
\hline Etniksiti & Sangat Setuju & Setuju & Kurang Setuju & Tidak Setuju & Sangat Tidak Setuju & Jumlah \\
\hline Melayu & $3(4)$ & $16(21.3)$ & $11(14.7)$ & $33(44)$ & $12(16)$ & $75(100)$ \\
Cina & $4(5.3)$ & $15(20)$ & $32(42.7)$ & $21(28)$ & $3(4)$ & $75(100)$ \\
\hline Jumlah & $7(4.7)$ & $31(20.7)$ & $43(28.7)$ & $54(36)$ & $15(10)$ & $150(100)$ \\
\hline
\end{tabular}

Jadual 23. Dasar 1Malaysia menekankan prinsip keadilan (peratusan dalam parentesis).

\begin{tabular}{ccccccc}
\hline Etniksiti & Sangat Setuju & Setuju & Kurang Setuju & Tidak Setuju & Sangat Tidak Setuju & Jumlah \\
\hline Melayu & $6(8)$ & $38(50.7)$ & $24(32)$ & $4(5.3)$ & $3(4)$ & $75(100)$ \\
Cina & $7(9.3)$ & $17(22.7)$ & $32(42.7)$ & $15(20)$ & $4(5.3)$ & $75(100)$ \\
\hline Jumlah & $13(8.7)$ & $55(36.7)$ & $56(37.3)$ & $19(12.7)$ & $7(4.7)$ & $150(100)$ \\
\hline
\end{tabular}


Jadual 24. Di bawah Dasar 1Malaysia, perpaduan rakyat yang berbilang kaum dapat dikukuhkan (peratusan dalam parentesis).

\begin{tabular}{ccccccc}
\hline Etniksiti & Sangat Setuju & Setuju & Kurang Setuju & Tidak Setuju & Sangat Tidak Setuju & Jumlah \\
\hline Melayu & $19(25.3)$ & $33(44)$ & $17(22.7)$ & $5(6.7)$ & $1(1.3)$ & $75(100)$ \\
Cina & $5(6.7)$ & $4(5.3)$ & $23(30.7)$ & $25(33.3)$ & $18(24)$ & $75(100)$ \\
\hline Jumlah & $24(16)$ & $37(24.7)$ & $40(26.7)$ & $30(20)$ & $19(12.7)$ & $150(100)$ \\
\hline
\end{tabular}

Jadual 25. Pengamalan Dasar 1Malaysia selaras dengan slogannya 'Rakyat Didahulukan, Pencapaian Diutamakan' (peratusan dalam parentesis).

\begin{tabular}{ccccccc}
\hline Etniksiti & Sangat Setuju & Setuju & Kurang Setuju & Tidak Setuju & Sangat Tidak Setuju & Jumlah \\
\hline Melayu & $20(26.7)$ & $28(37.3)$ & $18(24)$ & $7(9.3)$ & $2(2.7)$ & $75(100)$ \\
Cina & $7(9.3)$ & $15(20)$ & $30(40)$ & $19(25.3)$ & $4(5.3)$ & $75(100)$ \\
\hline Jumlah & $27(18)$ & $43(28.7)$ & $48(32)$ & $26(17.3)$ & $6(4)$ & $150(100)$ \\
\hline
\end{tabular}

Jadual 26. Dasar 1Malaysia selaras dengan konsep kebersamaan dalam satu keluarga besar (peratusan dalam parentesis)

\begin{tabular}{ccccccc}
\hline Etniksiti & Sangat Setuju & Setuju & Kurang Setuju & Tidak Setuju & Sangat Tidak Setuju & Jumlah \\
\hline Melayu & $18(24)$ & $36(48)$ & $18(24)$ & $1(1.3)$ & $2(2.7)$ & $75(100)$ \\
Cina & $9(12)$ & $13(17.3)$ & $47(62.7)$ & $5(6.7)$ & $1(1.3)$ & $75(100)$ \\
\hline Jumlah & $27(18)$ & $49(32.7)$ & $65(43.3)$ & $6(4)$ & $3(2)$ & $150(100)$ \\
\hline
\end{tabular}

Jadual 27. Dasar 1Malaysia memberi kesan yang baik untuk masyarakat (peratusan dalam parentesis).

\begin{tabular}{ccccccc}
\hline Etniksiti & Sangat Setuju & Setuju & Kurang Setuju & Tidak Setuju & Sangat Tidak Setuju & Jumlah \\
\hline Melayu & $23(30.7)$ & $27(36)$ & $22(29.3)$ & $2(2.7)$ & $1(1.3)$ & $75(100)$ \\
Cina & $9(12)$ & $10(13.3)$ & $49(65.3)$ & $7(9.3)$ & $0(0)$ & $75(100)$ \\
\hline Jumlah & $32(21.3)$ & $37(24.7)$ & $71(47.3)$ & $9(6)$ & $1(0.7)$ & $150(100)$ \\
\hline
\end{tabular}

Menurut pendapat kaum Melayu, Dasar 1Malaysia banyak memberikan kesan positif kepada masyarakat. Orang Melayu berasa negara kita sangat memerlukan Dasar 1Malaysia demi kebaikan semua pihak daripada pelbagai aspek pembangunan negara. Walaupun kebanyakan orang Cina yang tidak berpuas hati tentang perkara berkaitan dasar ini dan berpendapat (68\%) bahawa dasar tersebut tidak memberikan banyak implikasi terhadap pembangunan negara. Bagi orang Melayu pula Dasar 1Malaysia ada membawa perubahan yang ketara terhadap negara kita apabila $30.7 \%$ dan 29.3\% mereka tidak setuju dan sangat tidak setuju dengan ayat tersebut (Jadual 6). Orang Melayu (53.4\%) berpendirian bahawa Dasar 1Malaysia akan dapat menjadikan pentadbiran negara lebih lancar, berbanding dengan $32 \%$ bagi orang Cina (Jadual 20). Bagi orang Melayu (69.3\%), dengan adanya Dasar 1Malaysia, perpaduan rakyat yang berbilang kaum di Malaysia dapat dikukuhkan, tetapi hanya segelintir 12\% sahaja orang Cina percaya bahawa 
perkara ini dapat dicapai (Jadual 24). Bagi pernyataan bahawa tidak ada golongan yang akan dipinggirkan, rata-rata bangsa Melayu dan bangsa Cina tidak tentu mempunyai harapan yang melambung bahawa ini dapat dilaksanakan apabila hanya $47 \%$ dan $26.3 \%$ bangsa masing-masing setuju dan sangat setuju dengan ayat tersebut (Jadual 21). Untuk pernyataan adakah Dasar 1Malaysia memberikan kesan yang baik untuk masyarakat, 66.7\% mengatakan setuju dan sangat setuju dengan pernyataan ini, manakala hanya $25.3 \%$ sahaja orang Cina mempunyai pendapat yang sama.

Dapatan kajian juga menunjukkan bahawa orang Melayu percaya bahawa Dasar 1Malaysia akan dapat menolong BN untuk menebus balik kemerosotan dalam memperoleh sokongan dan kekalahan di lima negeri pada PRU-12. Sebaliknya, bagi orang Cina mereka tetap berpendirian bahawa walaupun banyak bantuan dan kemudahan yang ditawarkan oleh pihak kerajaan, Dasar 1Malaysia belum cukup lagi untuk menebus kekalahan BN yang lalu.

\section{RUMUSAN DAPATAN KAJIAN DAN KESIMPULAN}

Keseluruhannya, kaji selidik ini telah berjaya merungkai serta menjawab objektif yang telah ditetapkan. Perdebatan terbuka berkenaan dengan Dasar 1Malaysia ini amat penting bagi memastikan dasar ini dapat mencapai matlamat yang telah ditetapkan. Dasar 1Malaysia merupakan satu dasar yang amat baik diketengahkan oleh kerajaan. Namun begitu, kelompongan dalam pelaksanaan dasar mungkin mengakibatkan dasar ini tidak seperti yang dirancang oleh pihak kerajaan. Kaum Cina melihat pelaksanaan dasar ini dapat memberikan keadilan serta kesaksamaan kepada semua kaum di Malaysia pada mulanya, namun setelah beberapa lama dilaksanakan dasar ini hanya dilihat mereka sebagai retorik politik untuk BN sebagai kerajaan memperkukuh kuasa mereka.

Perlaksanaan dasar dibuat oleh penjawat awam yang terdiri hampir keseluruhannya daripada Orang Melayu. Penjawat awam penting dalam proses politik kerana mereka mentafsirkan dan menginterpretasikan peraturan, undangundang dan keputusan kerajaan (Gerston, 2004). Pentafsiran mereka boleh dipengaruhi oleh nilai, norma, kepercayaan, etnik dan ideologi mereka, dan ini boleh menyebabkan tindakan atau kelakuan mereka boleh menjadi berat sebelah.

Sebagai contoh, ketidakseimbangan perwakilan kaum dalam perkhidmatan awam jelas mencerminkan kegagalan Dasar 1Malaysia yang diuar-uarkan oleh pihak kerajaan. Penguasaan birokrasi oleh orang Melayu mencerminkan tujuan memberikan pekerjaan kepada orang Melayu dan mengekalkan kuasa pentadbiran di tangan orang Melayu (Lim, 2007). Sehingga hari ini penguasaan orang Melayu dalam birokrasi masih kukuh walaupun pengenalan Dasar 1Malaysia telah dilaksanakan kerajaan BN. Ini merupakan salah satu kelompongan yang dilihat oleh kaum Cina sebagai retorik pelaksanaan Dasar 1Malaysia. Ketidakseimbangan perwakilan kaum dalam perkhidmatan awam harus ditangani oleh kerajaan dengan pelaksanaan Dasar 1Malaysia.

Secara keseluruhannya, Dasar 1Malaysia telah menarik perhatian responden berbangsa Melayu dan Cina. Bantuan masyarakat seperti pertolongan 1Malaysia yang telah dihulurkan oleh pihak kerajaan memang ada membawa manfaat kepada rakyat Malaysia. Namun, responden Cina lebih melihat bahawa langkah pihak kerajaan tersebut hanyalah untuk menarik perhatian rakyat. Malah, ada yang melabelkan bahawa segala bantuan tersebut hanyalah pembaziran. Rata-rata orang Melayu berpuas hati terhadap Dasar 1Malaysia kerana bagi kebanyakan mereka (69.3\%), dasar ini adalah benar-benar bertepatan dengan slogannya iaitu 'Rakyat Didahulukan, Pencapaian Diutamakan', tetapi hanya $12 \%$ sahaja orang Cina berpendapat begitu (Jadual 24).

Bagi kaum Cina, mereka mengkehendaki layanan yang sama rata. Mereka juga mahu kerajaan membela kepentingan serta nasib mereka sama seperti kaum lain. Mereka masih percaya bahawa Dasar 1Malaysia hanya akan mengutamakan dan menguntungkan orang Melayu. Dari sudut pandangan kaum Melayu pula, rata-rata mereka berasa khuatir sekiranya hak-hak keistimewaan yang dinikmati mereka selama ini terhapus. Namun begitu orang Melayu dan sebilangan orang Cina yakin bahawa Dasar 1Malaysia mampu memacukan arus pembangunan negara. 
Akhirnya, menurut kedua-dua bangsa itu Dasar 1Malaysia merupakan satu konsep yang tidak sukar untuk difahami. Kebanyakan responden berpendapat bahawa Dasar 1Malaysia merupakan satu dasar yang jelas, praktikal dan pragmatik.

\section{RUJUKAN}

Anderson, J. E. (2015). Public Policymaking. Edisi Ke-8. Stamford, CT, USA: Cengage Learning.

Bahagian Penerbitan Dasar Negara (2009). Satu Malaysia Rakyat Didahulukan Diutama. Dalam http://www.kpkk. gov.my/pdf/Booklet_1MALAYSIA.PDF.

Baumer, D. C., \& Van Horn, C. E. (2014). Politics and Public Policy: Strategic Actors and Policy Domain. Edisi Ke4. Los Angeles: SAGE CQ Press.

Bridgman, P., \& Davis, G. (1999). Australian Policy Handbook. St. Leonards, NSW, Aust.: Allen \& Unwin.

Denhardt, R. B., Denhardt, J. V., \& Blanc, T. A. (2014). Public Administration: An Action Orientation. Boston, MA, USA: Wadsworth, Cengage Learning.

Dye, T. R. (1992). Understanding Public Policy. Edisi Ke-7. New Jersey” Prentice Hall.

Easton, D. (1957). An approach to the analysis of political system. World Politics: A Quarterly Journal of International Relations, 9(3), 383-400.

Gerston, L. N. (2004). Public Policy Making: Process and Principles. Armonk, New York: M.E. Sharpe.

Howlett, M., \& Ramesh. M. (1995). Studying Public Policy: Policy Cycle and Policy Subsystems. Toronto: Oxford University Press.

Hughes, O. E. (1998). Public Management and Administration: An Introduction. London: Macmillan Press Ltd.

Hussain, A. A. (2002). Politik dan Dasar Awam Malaysia. Utusan Publications \& Distributors Sdn Bhd: Kuala Lumpur.

Jenkins, B. (1993). Policy analysis - Models and Approaches. In M. Hill (Penyuntin). The Policy Process: A Reading. New York: Harvester Wheatsheaf. ms. 34-44.

Kernaghan, K., \& Siegel, D. (1999). Public Administration in Canada. Edisi Ke-4. Toronto: International Thompson Publishing.

Khairi, A. (2011). Konsep 1Malaysia \& cabaran perlaksanaannya ke arah pemantapan perpaduan sesebuah negara bangsa. Sosiohumanika, 4(1). 129-140.

Lasswell, H. D., \& Kaplan, A. (1970). Power and Society. New Haven, CT: Yale University Press.

Lim, H. H. (2007). Improving administrative performance in Malaysia: The more difficult next steps in reform. Policy and Society, 26(2), 33-59. doi: 10.1016/ S1449-4035(07)70107-8.

Lowi, T. (1972). Four systems of politics, policy and choice. Public Administration Review, 32, 298-310.

Ripley, R. B., \& Franklin, G. A. (1987). Congress, the Bureaucracy and Public Policy. Chicago: Dorsey Press.

Sinar Harian (2012). Kajian: IMalaysia Diterima, tapi Tanggapan Kaum Masih Sempit. Dalam http://www. sinarharian.com.my/mobile/nasional/kajian-1malaysia-diterima-tapi-tanggapan-kaum-masih-sempit1.24919

SPR (2008). Kedudukan Kerusi Dewan Rakyat yang Dimenangi. Dalam http://semak.spr.gov.my/spr/module/5_ KerusiDRphp

Turner, M., \& Hulme, D. (1997). Governance, Administration and Development: Making the State Work. London: Macmillan Press.

Van der Berg, H. (2001). Economic Growth and Development: An Analysis of Our Greatest Economic Achievements and Our Most Exciting Challenges. Boston: McGraw-Hill Irwin.

Wikipedia (2008). Pilihan Raya Umum Malaysia 2008. Dalam https://ms.wikipedia.org/wiki/Keputusan_Pilihan_ Raya_umum_Malaysia_2008.

Yacob, N. H., (2011). Konsep Al-Wassatiyyah Dalam Gagasan 1Malaysia: Satu Analisis. Pusat Kajian Pengurusan Pembangunan Islam (ISDEV). Pusat Pengajian Sains Kemasyarakatan, Universiti Sains Malaysia. 